\title{
Effects of temperature on global patterns of tuna and billfish richness
}

\author{
Daniel G. Boyce* ${ }^{*}$ Derek P. Tittensor, Boris Worm \\ Department of Biology, Dalhousie University, Halifax, Nova Scotia B3H 4J1, Canada
}

\begin{abstract}
Although tunas and billfishes are of substantial economic importance and conservation concern, global patterns of diversity and distribution remain poorly understood. Many species are highly migratory and able to tolerate a wide thermal range. In the present study, ambient water temperature data for 18 species of tuna and billfish from 190 literature sources were combined according to geographical location. An empirical modelling approach was used to relate temperature tolerances of tunas and billfishes to their global diversity patterns. Mean preferred and tolerated temperature ranges were calculated for each species in the adult and juvenile life stages. Mean tolerance data were then overlaid in order to fit models relating the species richness of tunas and billfishes to ambient water temperature. The best-fit model was used in conjunction with gridded water temperature data to predict global species richness patterns. Cumulative species richness predictions from water temperature data were positively correlated with observed longline-derived richness data $(\mathrm{r}=0.577, \mathrm{p}<0.0001)$. Diversity consistently peaked at intermediate latitudes $\left(10\right.$ to $35^{\circ} \mathrm{N}$ and $\mathrm{S}$ ) in a manner similar to other pelagic taxa. This analysis provides evidence that the ambient water temperature tolerances of tunas and billfishes can be used to predict broad species richness patterns on a global scale.
\end{abstract}

KEY WORDS: Tuna - Billfish - Temperature - Species richness - Diversity · Global distribution · Habitat $\cdot$ Heterothermic

\section{INTRODUCTION}

Tunas (Family: Scombridae; genus: Thunnus) and billfishes (Families: Xiphidae and Istiophoridae) are highly migratory apex predators of the global open ocean that have been exploited for centuries (Block et al. 2001). Several species have been greatly depleted in abundance (Safina 1998, Myers \& Worm 2003, NMFS 2005, ICCAT 2006), raising concerns about the sustainability of high-seas fisheries (but see Sibert et al. 2006 for an alternative view regarding tropical Pacific tunas).

While tagging studies have added to our knowledge of the current ranges and distribution patterns for individual species of tuna and billfish (Block et al. 2001), community-wide patterns of abundance and richness remain poorly understood (Worm et al. 2005). Knowledge of these patterns and the oceanographic or biological factors that drive them may be important for the effective management of global populations of tunas and billfishes.

Tunas and billfishes are unique among teleost fishes in being regionally heterothermic. Vascular countercurrent heat exchangers (retia) in the bodies and heads of most species maintain internal temperatures above those of the ambient environment, allowing these fishes to exploit a wide range of oceanic habitats. Despite these adaptations, the upper and lower bounds of individual species geographic ranges appear to relate to their physiological temperature tolerances (Brill 1994, Brill \& Lutcavage 2001). In addition to water temperature, factors such as oxygen content, prey availability, ocean fronts, zooplankton, salinity, islands, seamounts, and the presence of other organisms (seabirds, porpoises) have been hypothesized to correlate with the abundance and distribution of these species (Sund et al. 1981, Block \& Stevens 2001, Worm 
et al. 2005). Of these, water temperature has repeatedly emerged as the best single predictor of species density and distribution (Lee et al. 2005, Worm et al. 2005). This suggests that ambient water temperature may be used to predict the species richness patterns of tunas and billfishes on a global scale.

The present study uses an empirical modelling approach to investigate the role of water temperature in driving global species richness patterns of tunas and billfishes. Ambient water temperature data gathered from 190 published studies were compiled and analyzed to predict global richness patterns for 18 species of tuna and billfish. The accuracy of predictions was tested against patterns of rarefied species diversity derived from Japanese pelagic longline logbook data (from 1952 to 1999). Japanese logbook data are compiled from the world's largest longline fleet and are the only globally consistent data on species composition, catch, and effort for all tunas and billfishes (Worm et al. 2005). We hypothesize that observed patterns of diversity could be independently reconstructed using data on individual species temperature tolerances.

\section{METHODS}

Database. We searched marine and fisheries journals and databases published between January 1950 and April 2006 to extract information on the water temperature tolerances of tuna and billfish species. All species of tuna (Family: Scombridae; genus: Thunnus) and billfish were included, as well as skipjack Katsuwonus pelamis, slender tuna Allothunnus fallai, little tunny Euthynnus alletteratus and kawakawa E. affinis. These species were selected as they are all regionally heterothermic predators that share common ecological niches, are fished with like gear, and exhibit comparable oceanographic preferences (reviewed by Sund et al. 1981, Brill \& Lutcavage 2001, reviewed by Worm et al. 2005). A total of 190 publications were identified and entered into a database. Primary data sources included fisheries data, satellite tracking, acoustic tracking, ultrasonic telemetry, aerial surveys, and captive studies. For each species, temperature information was categorized into minimum and maximum water temperature tolerances $\left(T_{\min }, T_{\max }\right)$ and preferences $\left(P_{\min }, P_{\max }\right)$. Temperature tolerances represent the minimum and maximum documented water temperatures in which the species was found. Temperature range $(R)$ is $T_{\max }-T_{\min }$. Temperature preference represents the temperature range within which the species spent the plurality ( $>40 \%$ ) of its time for the duration of the study.

Measurements of temperative tolerance and preference were compiled for 18 species of tuna and billfish in the adult ( $>5 \mathrm{yr}$ ), juvenile ( 1 to $5 \mathrm{yr}$ ), and larval ( 0 to
1 yr) life stages, contingent on data availability. Temperature studies were sparse for kawakawa and little tunny and lacking for longtail tuna Thunnus tonggol, blackfin tuna Thunnus atlanticus, shortbill spearfish Tetrapturus angustirostris, longbill spearfish Tetrapturus pfluegeri and Mediterranean spearfish Tetrapturus pelone. Species for which temperature studies were not available were omitted from the analysis.

Statistical analysis. Using the database, mean temperature tolerance, preference, and absolute temperature tolerance were calculated across studies for each of the 18 species of tuna and billfish. Averages were calculated separately for each combination of life stage and species. Species richness was calculated from mean temperature tolerances as the total number of species reported to occur at a given temperature, using $1^{\circ} \mathrm{C}$ increments. Second-, third-, and fourth-order polynomial linear regression models were fitted to these data and checked for fit using Akaike Information Criterion (AIC) values, after testing assumptions of normality and homogeneity of variance. Inverse polynomial and generalized linear models with a Poisson error structure were also fitted to the data.

Using the best-fit third-order polynomial model (lowest AIC value of those tested) we predicted species richness from water temperature using published global mean water temperature data at 0,50 , and $100 \mathrm{~m}$ depth on a $5^{\circ}$ grid, derived from the NOAA World Ocean Atlas 2001 (Conkright et al. 2002). The most accurate depth for predicting global species richness was determined by calculating a leastsquares linear regression of temperature-predicted species richness against rarefied species richness derived from Japanese longline data for each $5^{\circ} \times$ $5^{\circ}$ cell $(\mathrm{n}=1983$ cells). This procedure was carried out for all 3 depths $(0,50,100 \mathrm{~m})$, and for each of the past 5 decades (1952 to 1999). The longlining data set encompasses the estimated global range of all tuna and billfish species, excluding some coastal areas within individual countries' Exclusive Economic Zones.

Direct spatial comparison of predicted and rarefied species richness would be injudicious, even when normalized, due to differences in scaling between predicted and rarefied values. Although we assumed that rarefaction correctly orders cells in terms of relative species richness, the difference between rarefied and actual (asymptotic) species richness values varies between cells. Therefore, in order to assess the spatial accuracy of our predictions, we compared patterns of relative species richness for each model, examining spatial locations of high and low richness and the correspondence of these areas between models. To do this, we binned both rarefied species richness and predicted species richness (at $100 \mathrm{~m}$ ) into percentiles, and compared the difference between these 2 sets of percentiles. 
Fig. 1. (A) Overall (white) and mean (grey) ambient water temperature tolerances and preferences (black bars) for 18 species of adult tuna and billfish as derived from the database. (B) Mean temperature tolerances (white) and preferences (black) for larval (0-1 yr), juvenile (1-5 yr), and adult (>5 yr) life stages for 18 species of tuna and billfish. Values in parentheses represent the number of studies included

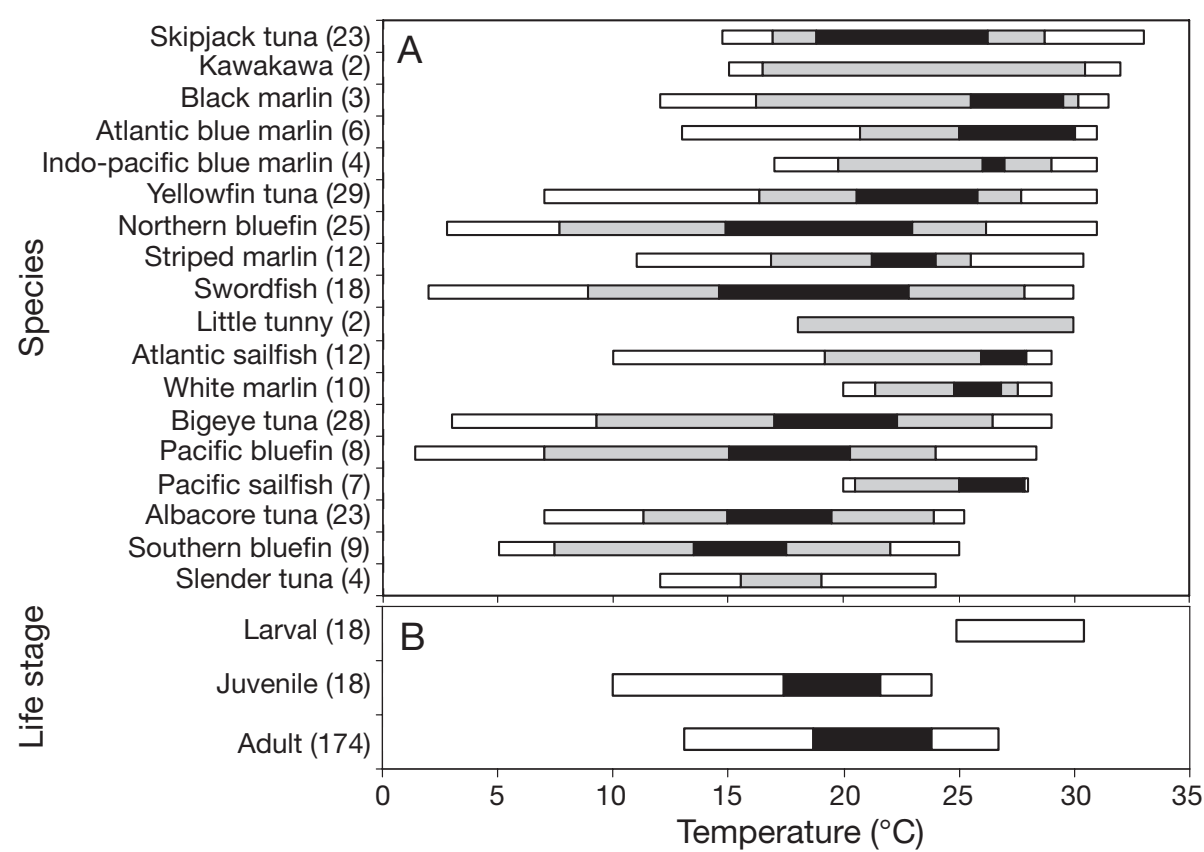

their mean tolerance range. Furthermore, marlins, sailfishes, and many small tropical tunas (kawakawa, little tunny, and skipjack) were less tolerant of low water temperatures than the larger species of tuna and billfish (bluefin, bigeye, yellowfin, and swordfish) (Table 1, Fig. 1A).

Data for each life stage were analyzed separately in order to compare the mean temperature tolerances and preferences for adult, juvenile and larval life stages of each species (Table 1, Fig. 1B). Results indicated that spawning occurs in waters that are much warmer $\left(\Delta T \approx 5^{\circ} \mathrm{C}\right)$ than those typically inhabited by (2 species) were skewed towards the warmer end of

Table 1. Overall (Min., Max.), and mean ( $\left.T_{\min }, T_{\max }\right)$ temperature tolerances, preferences $\left(P_{\min }, P_{\max }\right)$ and mean tolerance ranges

$(R)$ in ${ }^{\circ} \mathrm{C}$ for 18 species of tuna and billfish in the adult $(>5 \mathrm{yr})$ life stage. A: Atlantic; P: Pacific; I: Indian; - : not available

\begin{tabular}{|llccccccccc|}
\hline & & Ocean & Min. & Max. & $T_{\min }$ & $T_{\max }$ & $P_{\min }$ & $P_{\max }$ & $R$ & No. of sources \\
\hline Northern bluefin & Thunnus thynnus & $\mathrm{A}$ & 2.8 & 31 & 7.63 & 26.17 & 14.90 & 22.93 & 18.54 & 25 \\
Southern bluefin & Thunnus maccoyii & $\mathrm{A}, \mathrm{P}, \mathrm{I}$ & 5 & 25 & 7.42 & 22.00 & 13.50 & 17.50 & 14.58 & 9 \\
Pacific bluefin & Thunnus orientalis & $\mathrm{P}, \mathrm{I}$ & 5 & 28.4 & 6.98 & 24.00 & 15.00 & 20.25 & 17.02 & 8 \\
Bigeye tuna & Thunnus obesus & $\mathrm{A}, \mathrm{P}, \mathrm{I}$ & 3 & 29 & 9.25 & 26.45 & 16.95 & 22.32 & 17.20 & 28 \\
Yellowfin tuna & Thunnus albacares & $\mathrm{A}, \mathrm{P}, \mathrm{I}$ & 7 & 31 & 16.35 & 27.73 & 20.53 & 25.79 & 11.37 & 29 \\
Albacore tuna & Thunnus alalunga & $\mathrm{A}, \mathrm{P}, \mathrm{I}$ & 7 & 25.2 & 11.29 & 23.90 & 14.93 & 19.47 & 12.61 & 23 \\
Skipjack tuna & Katsuwonus pelamis & $\mathrm{A}, \mathrm{P}, \mathrm{I}$ & 14.7 & 33 & 16.90 & 28.76 & 18.84 & 26.23 & 11.86 & 23 \\
Kawakawa & Euthynnus affinis & $\mathrm{P}, \mathrm{I}$ & 15 & 32 & 16.50 & 30.50 & - & - & 14.00 & 2 \\
Slender tuna & Allothunnus fallai & $\mathrm{A}, \mathrm{P}, \mathrm{I}$ & 12 & 24 & 15.50 & 19.00 & - & - & 3.50 & 4 \\
Little tunny & Euthynnus alletteratus & $\mathrm{A}$ & 18 & 30 & 18.00 & 30.00 & - & - & 12.00 & 2 \\
Swordfish & Xiphias gladius & $\mathrm{A}, \mathrm{P}, \mathrm{I}$ & 2 & 30 & 8.89 & 27.86 & 14.57 & 22.83 & 18.97 & 18 \\
Indo-pacific blue marlin & Makaira mazara & $\mathrm{P}, \mathrm{I}$ & 17 & 31 & 19.75 & 29.05 & 26.00 & 27.00 & 9.30 & 4 \\
Atlantic blue marlin & Makaira nigricans & $\mathrm{A}$ & 13 & 31 & 20.68 & 30.05 & 25.00 & 30.00 & 9.37 & 6 \\
White marlin & Tetrapturus albidus & $\mathrm{A}$ & 20 & 29 & 21.33 & 27.57 & 24.80 & 26.85 & 6.23 & 10 \\
Black marlin & Makaira indica & $\mathrm{A}, \mathrm{P}, \mathrm{I}$ & 12 & 31.5 & 16.17 & 30.17 & 25.50 & 29.50 & 14.00 & 3 \\
Striped marlin & Tetrapturus audax & $\mathrm{P}, \mathrm{I}$ & 11 & 30.4 & 16.82 & 25.49 & 21.23 & 24.00 & 8.67 & 12 \\
Atlantic sailfish & Istiophorus albicans & $\mathrm{A}$ & 10 & 29 & 19.20 & 27.90 & 25.95 & 27.85 & 8.70 & 12 \\
Pacific sailfish & Istiophorus platypterus & $\mathrm{P}, \mathrm{I}$ & 20 & 28 & 20.50 & 27.85 & 25.00 & 27.80 & 7.35 & 7 \\
\hline
\end{tabular}


juveniles or adults, and which have temperatures that are often on the upper fringes of the reported mean adult temperature tolerance range; this was the case, for example, in southern and pacific bluefin tunas and albacore tuna (Table 1, Fig. 1).

Polynomial regression fits of tuna and billfish species richness against water temperature (Fig. 2A), predicted peak richness at a lower temperature $\left(T_{\text {optimum }}\right)$ for Thunnus $\left(\sim 21^{\circ} \mathrm{C}, \mathrm{r}^{2}=0.976\right)$ than for Istiophoridae and Xiphidae $\left(\sim 24^{\circ} \mathrm{C}, \mathrm{r}^{2}=0.919\right)$. Comparisons across ocean basins (Fig. 2B) predicted higher maximum species richness in the Indo-Pacific (11 species, $T_{\text {optimum }} \approx 22^{\circ} \mathrm{C}$, $\mathrm{r}^{2}=0.978$ ) than the Atlantic (9 species, $T_{\text {optimum }} \approx 21^{\circ} \mathrm{C}, \mathrm{r}^{2}=0.979$ ). Total species richness against water temperature was best approximated by a third-order polynomial regression model yielding a predicted peak in species richness at a water temperature of $T_{\text {optimum }} \approx 22.5^{\circ} \mathrm{C}\left(\mathrm{r}^{2}=0.978\right)$ (Fig. $2 \mathrm{C}$ ).

Patterns of species richness were predicted from ambient water temperature at depths of 0,50 and $100 \mathrm{~m}$ (Table 2). When plotted against normalized rarefied species richness from the 1990s, there was a higher degree of correlation at $100 \mathrm{~m}(\mathrm{r}=0.577, \mathrm{p}<0.0001)$ (Fig. 3A) than at $0 \mathrm{~m}(\mathrm{r}=0.282, \mathrm{p}<0.0001)$ or $50 \mathrm{~m}(\mathrm{r}=0.420, \mathrm{p}<0.0001)$ (Table 2). Correlations tended to strengthen marginally over time. Spatial patterns of temperature-predicted species richness at $100 \mathrm{~m}$ (Fig. 3B) appeared to coincide reasonably well with longline derived estimates (Fig. 3C). Maximum predicted and observed global species richness both occurred at intermediate latitudes (10 to $35^{\circ} \mathrm{N}$ and $\mathrm{S}$ ), and decreased towards polar and equatorial regions.

Species richness predictions at $100 \mathrm{~m}$ depth and rarefied species richness estimates from the 1990s were binned into percentiles to compare spatial patterns of relative species richness (Fig. 4A,B). Differences between predicted and rarefied percentiles were calculated for each $5^{\circ}$ cell and plotted to assess the regional accuracy of our model (Fig. 4C). The largest discrepancies were noted for mid-latitudinal regions of the Atlantic and Indian Oceans, where the model appeared to over-predict relative species richness (Fig. 4C). The model under-predicted relative species richness in the northwest Atlantic and Pacific Oceans (Fig. 4C).
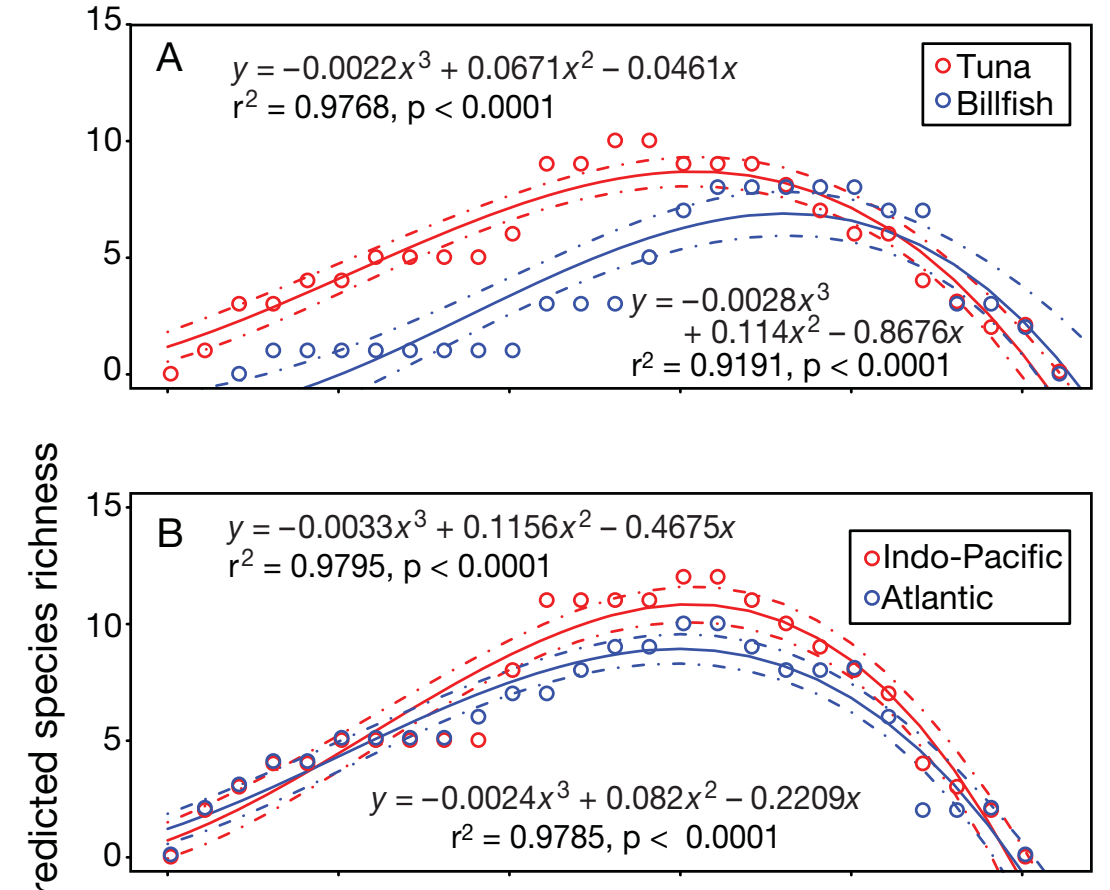

a

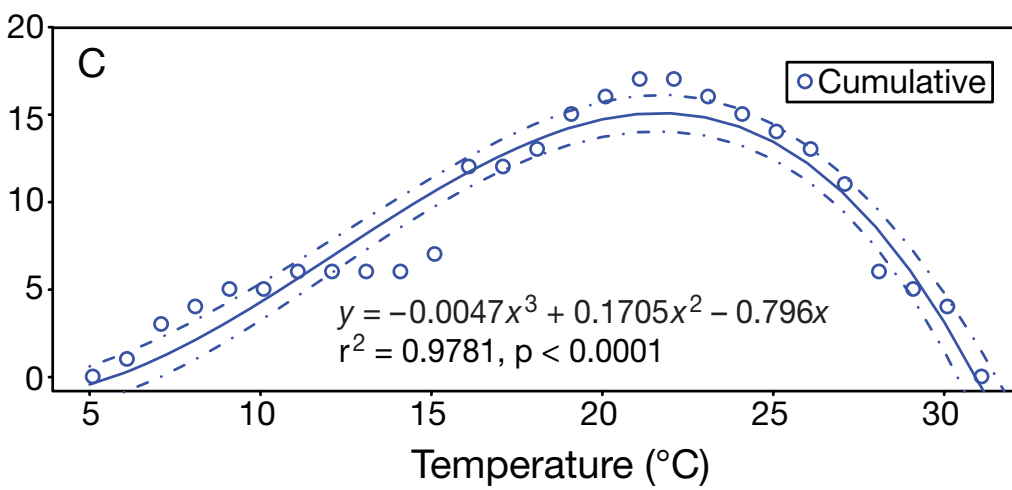

Fig. 2. Third-order polynomial regression fits of predicted species richness against water temperature for (A) Scombridae: Thunnini: $y=-0.0022 x^{3}+0.0671 x^{2}$ $-0.0461 x$ (red) and Istiophoridae and Xiphidae: $y=-0.0028 x^{3}+0.114 x^{2}-0.8676 x$ (blue); (B) Indian/Pacific: $y=-0.0033 x^{3}+0.1156 x^{2}-0.4675 x$ (red) and Atlantic: $y=-0.0024 x^{3}+0.082 x^{2}-0.2209 x$ (blue); and (C) cumulative (all 18 species, all oceans): $y=-0.0047 x^{3}+0.1705 x^{2}-0.796 x$. Dashed lines represent $95 \%$ confidence intervals

Table 2. Pearson correlation coefficients (r) of tuna and billfish species richness predicted using temperature at 3 different water depths against rarefied species richness (per 50 individuals) from Japanese longline data for 5 separate decades (1952-1999). SST: sea surface temperature

\begin{tabular}{|lccccc|}
\hline & & \multicolumn{5}{c|}{ Rarefied } \\
& $1952-1959$ & $1960-1969$ & $1970-1979$ & $1980-1989$ & $1990-1999$ \\
\hline Predicted & & & & & \\
SST & -0.211 & 0.052 & 0.190 & 0.248 & 0.282 \\
$50 \mathrm{~m}$ & -0.054 & 0.282 & 0.409 & 0.387 & 0.420 \\
$100 \mathrm{~m}$ & 0.378 & 0.591 & 0.657 & 0.606 & 0.577 \\
\hline
\end{tabular}



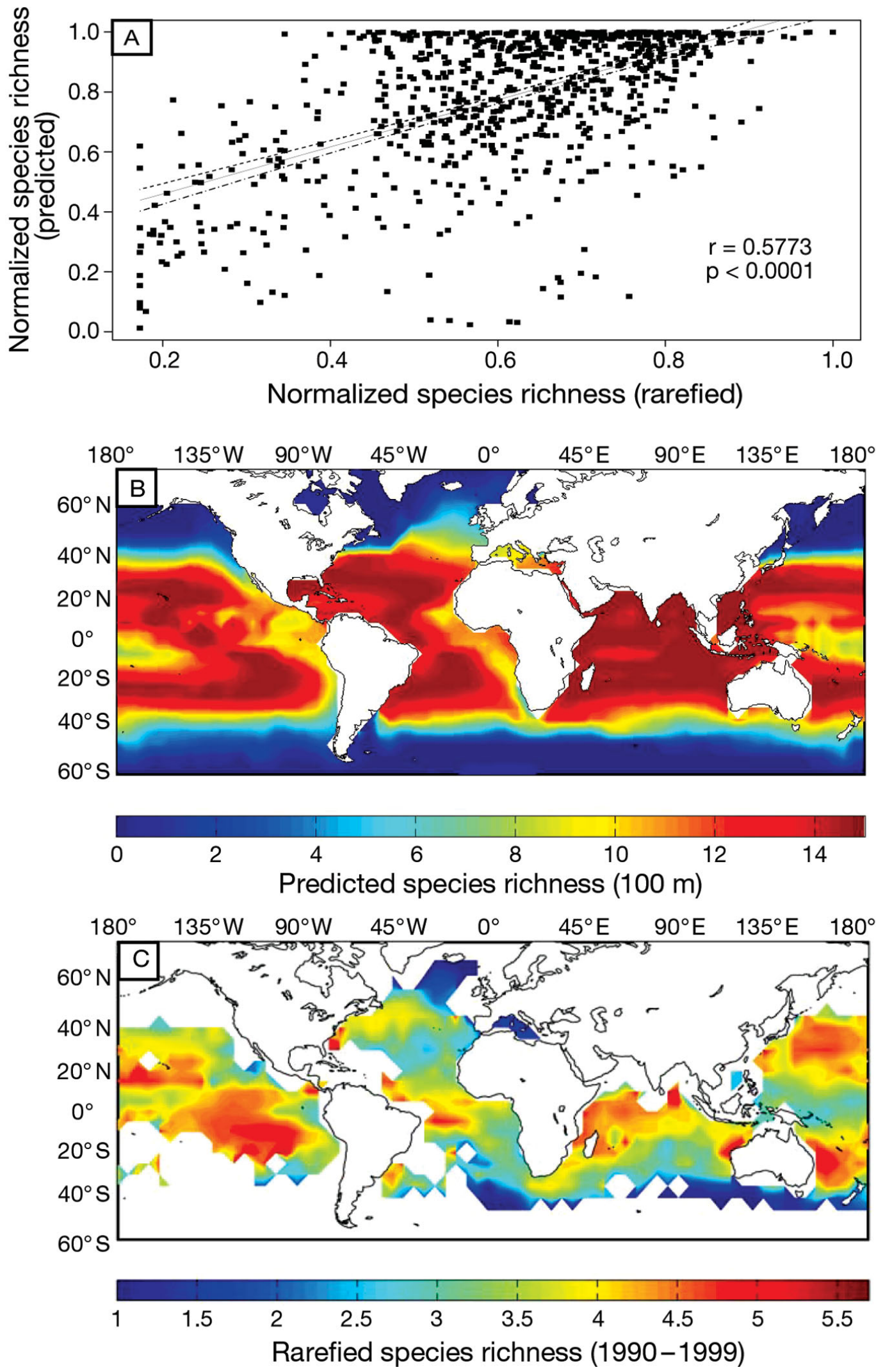

Fig. 3. (A) Linear regression fit of predicted species richness at $100 \mathrm{~m}$ depth against rarefied species richness from longlining data (1990-1999). (B) Temperature-predicted patterns of global tuna and billfish species richness at $100 \mathrm{~m}$ depth. (C) Rarefied tuna and billfish species richness per 50 individuals derived from Japanese longlining data (1990-1999) 

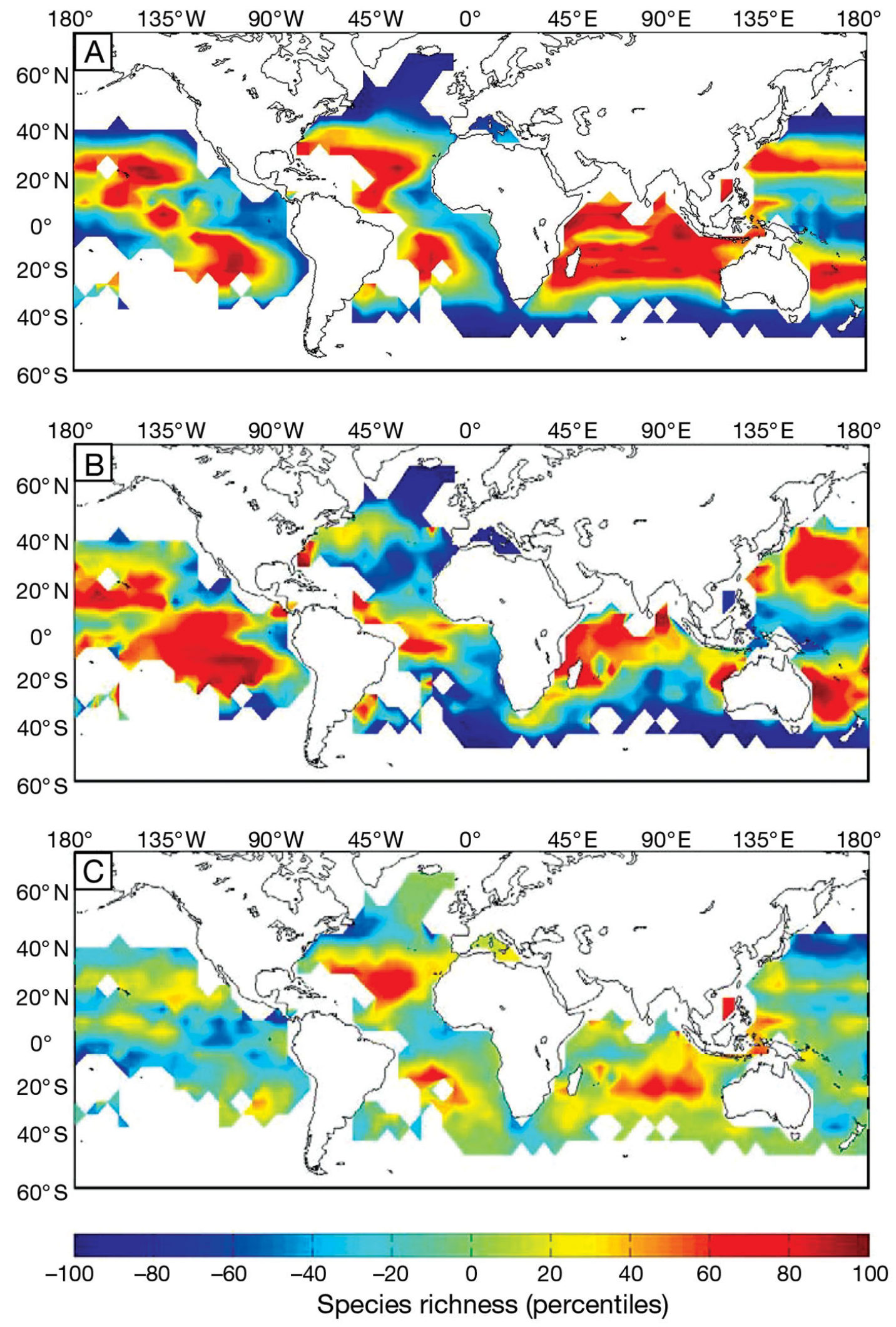

Fig. 4. (A) Percentiles of temperature-predicted patterns of global tuna and billfish species richness at $100 \mathrm{~m}$ depth. (B) Percentiles of rarefied tuna and billfish species richness derived from Japanese longlining data (1990-1999). (C) Predicted-minusrarefied percentiles. Positive values indicate overprediction of relative species richness; negative values indicate underprediction 


\section{DISCUSSION}

We examined the effects of ambient temperature tolerances on global species richness patterns for tunas and billfishes. The species with the widest temperature ranges were swordfish, bigeye, albacore and bluefin tunas (Fig. 1A). This is likely due to the fact that these species are more physiologically tolerant of colder temperatures, opening up a wider range of potential habitats, from temperate to sub-tropical waters. They also display longer migrations and deeper dives than other species of tuna and billfish (reviewed by Sund et al. 1981, Fromentin \& Fonteneau 2001). For example, bigeye tuna are capable of diving to depths of $600 \mathrm{~m}$ (Hanamoto 1987, Brill \& Lutcavage 2001) and northern bluefin are known to undertake trans-Atlantic migrations spanning a wide range of thermal habitats (Block et al. 2005). While temperature preferences for these species were centred around the mean tolerance, those for most marlins and sailfishes (Istiophoridae) were skewed towards the warm end of the mean tolerance distribution (Fig. 1A). Marlins and sailfishes are predominantly epipelagic, remaining largely within the upper mixed layer (Brill et al. 1993), with occasional dives as deep as $200 \mathrm{~m}$ (Block et al. 1992). As visual predators, billfishes maintain their brains (and eyes) at elevated temperatures in order to hunt in colder waters, and are unable to tolerate extremely cold temperatures for extended periods (except swordfish: Fritsches et al. 2005). In contrast, the more coldtolerant Thunnus spp. and swordfish are capable of diving to depths well below $200 \mathrm{~m}$, where temperatures are much lower. These species maintain elevated deep muscle temperatures which enable them to remain active in colder waters. Northern bluefin tuna, for example, can dive to depths in excess of $1000 \mathrm{~m}$, encountering an exceptionally wide thermal range (Block et al. 2005).

Unsurprisingly, marlins, sailfishes, and most small tropical tuna species (kawakawa, little tunny, and skipjack tuna) appeared to possess a higher tolerance for warmer waters and a lower tolerance for colder waters. A positive relationship between species body length and maximum temperature range was significant among tunas ( $\mathrm{r}=0.881, \mathrm{p}=0.0004)$ but not for billfishes $(r=0.456, p=0.297$, suggesting that body size may limit the thermal range for tunas but not billfishes. This finding is consistent with previous work on freshwater ectothermic fish species (Magnuson et al. 1979) and other tunas (Barkley et al. 1978, Sharp 1978), which found increased physiological temperature tolerance with increased body size. It is also possible that the larger thermal tolerance of some tunas has led to increased feeding and growth rates as a consequence of niche expansion and reduced competition, resulting in larger maximal body sizes relative to less coldtolerant tunas. Additionally, the variation in size, complexity, number, and positioning of heat-exchanging organs (retia) among different species of tuna results in varying degrees of heterothermy (Block \& Stevens 2001). For instance, several species maintain warm brains, and many larger species of tuna (albacore, bigeye, yellowfin, and bluefins) conserve heat in their viscera. This variation in heterothermy among tuna species of different sizes may partially explain why body size limits thermal range. Taken as a whole, the increase in temperature tolerance range with increasing body size among tunas is consistent with the theory that tunas were originally inshore tropical fishes which, through endothermic adaptations, became less vulnerable to environmental variability and reduced their competition with other species (Sharp 1978). The theory that tunas were originally tropical species is further supported by the need of their larvae for extremely warm waters (Fig. 1B).

When multiple species' temperature tolerance ranges were superimposed, predicted species richness for tunas and billfishes was a nonlinear function of water temperature (Fig. 2) best approximated by a thirdorder polynomial. Peak species richness was predicted to occur at $\sim 21^{\circ} \mathrm{C}$ for tunas and $24^{\circ} \mathrm{C}$ for billfishes (Fig. 2A). Given that tunas generally possess greater heterothermic capacities relative to billfishes (Dickson 1995), these results are consistent with previous studies. Accordingly, tunas generally are found in more temperate waters, migrate further and dive deeper than billfishes (except swordfish). Our billfish model was strongly driven by the inclusion of swordfishes (Xiphidae), which possessed a mean minimum temperature tolerance $10^{\circ} \mathrm{C}$ colder than the most cold-tolerant species of marlin or sailfish (Istiophoridae). Comparing ocean basins, highest species richness was predicted in the Indian and Pacific Oceans, followed by the Atlantic (Fig. 2B). Total global predicted species richness was strongly related to water temperature, with peak species richness predicted at $\sim 22.5^{\circ} \mathrm{C}\left(\mathrm{r}^{2}=0.978\right.$, $\mathrm{p}<0.0001$ ) (Fig. 2C).

Above-optimal temperatures appear to have a negative effect on richness. A decrease in species richness was documented in the western Pacific 'warm pool' (Worm et al. 2005), where the highest mean annual ocean temperatures at $100 \mathrm{~m}\left(>28^{\circ} \mathrm{C}\right)$ are found (Conkright et al. 2002). These temperatures are likely unsuitable for large tunas, which generate significant metabolic heat. For example, Atlantic bluefin tuna spawning in the similarly warm Gulf of Mexico were observed to undertake extended 'cooling' dives to deeper waters in between short spawning events at the surface (Teo et al. 2007). This may be a mechanism employed by adult fish to tolerate the high tempera- 
tures favourable for rapid larval development. Predicted species richness was better fit against estimated longlining diversity with both increasing depth and (generally) through time (Table 2). The improvement in fit with increasing water depth is best explained by the fact that $100 \mathrm{~m}$ is the most common depth at which longline hooks are set, resulting in the best fit against empirical longline data. The improvement in fit in more recent decades is potentially the result of more accurate empirical richness estimates due to the greater geographic distribution and magnitude of fishing effort by the Japanese longlining fleet in these decades.

In all oceans, predicted species richness peaked at intermediate latitudes (10 to $35^{\circ} \mathrm{N}$ and $\mathrm{S}$ ), with declining richness towards the poles and equator (Figs. 3A \& 4A). This latitudinal pattern was strongest for the Pacific Ocean, where 2 well-defined bands of peak species richness were observed (20 to $35^{\circ} \mathrm{N}$ and $\mathrm{S}$ ). In the Atlantic and Indian Oceans, predicted species richness peaks were more widely distributed, although still occurring at intermediate latitudes $\left(10\right.$ to $35^{\circ} \mathrm{N}$ and S) (Fig. 4A). This latitudinal pattern is similar to that previously found for the diversity of tunas and billfishes (Worm et al. 2003, 2005), as well as foraminifera and other zooplankton groups (Rutherford et al. 1999). It seems possible that the mid-latitudinal peaks of global species richness as predicted here may be similar across numerous taxonomic groups and trophic levels in the open oceans, and diverge from patterns previously found in terrestrial (Pianka 1966, Gaston 2000), coastal marine (Crame 2000), deep-sea benthic (Rex et al. 1993), and seaweed (Bolton 1994) communities, for which diversity typically peaks around the equator (Hillebrand 2004).

Spatial differences between predicted and rarefied models based on binned percentiles revealed overpredictions of relative species richness in the north and south Atlantic and southern Indian Oceans (Fig. 4C). Overpredictions of relative species richness in the Atlantic Ocean are possibly the result of prolonged and well-documented exploitation in this region (Myers \& Worm 2003) relative to the Pacific Ocean, where exploitation has been substantial but with a potentially lesser effect (Sibert et al. 2006). This is supported by a recent assessment from the United Nations Food and Agriculture Organization (Maguire et al. 2006), which indicated that 4 major tuna species (albacore, Atlantic and southern bluefin, and bigeye tunas) are overexploited or depleted in the Atlantic Ocean, whereas in the Indian and Pacific Oceans only 2 species are listed as fully exploited or depleted. Regions identified in the report as the most severely exploited included high seas tuna fishing grounds in the Atlantic and Indian Oceans, where the proportion of stocks classified as overexploited, depleted or recovering were between 46 and $66 \%$ of the total. Given the evidence for overexploitation, overpredictions in both the Atlantic and southern Indian Oceans are consistent with the hypothesis that exploitation of these species has caused shifts in species distributions. Taken as a whole, our predicted global species diversity peaks at around $2^{\circ} \mathrm{C}$ lower than that derived from longlining data. This difference may be related to variation in sampling methods, sampling depth, or other unmeasured covariates. Spawning behaviour of tunas and billfishes that prefer very warm waters may also account for the fact that optimal water temperature was lower in this study compared with longlining records, which may target spawning aggregations. Furthermore, longlining data included spearfishes Tetrapturus spp. but excluded many smaller tunas (kawakawa, little tunny, and slender tuna), all of which are included in the present data set; such variation may also be partly responsible for discrepancies. Despite this variation, there was a positive correlation between temperature-predicted species richness and richness obtained from longlining data (Fig 3A).

While temperature may be among the best global predictors for the distribution of these species, other factors are regionally important (Worm et al. 2005). Topographic features such as ocean fronts, reefs, shelf breaks and seamounts have been shown to be areas of high tuna and billfish abundance and diversity (reviewed by Worm et al. 2003). Similarly, oceanic fronts and eddies frequently attract tunas and billfishes (Sund et al. 1981, Laurs et al. 1984, Fiedler \& Bernard 1987, Santos 1994), likely because they can enhance and concentrate local productivity (Wolanski \& Hamner 1988, Oschlies \& Garçon 1998). As mean water temperature is not related to the occurrence of these habitat features, their effects on tuna and billfish abundance and richness have not been taken into account in this analysis.

Variation between the depth at which database temperature information was recorded and that used to predict ranges $(100 \mathrm{~m})$ is another possible source of error. The vast majority of information within the database was collected from subsurface tracking experiments such as satellite-tracking (Block et al. 2001), ultrasonic telemetry (Brill et al. 2002), and acoustic tracking (Bach et al. 2003). Such methods accurately record ambient water temperature regardless of depth. Using temperature at $100 \mathrm{~m}$ to predict patterns of richness when temperature information was gathered at a range of depths will likely not completely capture distribution patterns. Furthermore, it has been claimed that the position of tracking vessels can influence diving behaviour-and thus, temperature inhabited-for fish in tracking studies 
(Holts \& Bedford 1990). Variation in vertical distribution also occurs within species. For example, bigeye tuna catch rates as a function of depth have been shown to vary with latitude in the eastern tropical Pacific, possibly relating to zonal currents (Hanamoto 1974). This variation between the depth at which pelagic longline gear is set and the actual vertical distribution of each species may be an additional source of error. Nonetheless, our spatial analyses demonstrated high congruence between observed and temperature-predicted species richness.

Having identified some limitations of this study, several conclusions may be drawn. This analysis represents a comprehensive review of the effects of ambient temperature on global distribution patterns of tunas and billfishes. The ability to accurately identify key oceanographic variables, such as temperature, that underlie large-scale tuna and billfish range distributions may have implications for conservation and management. It allows prediction of the occurrence of tuna and billfish diversity hotspots and the effects of variation in temperature on those features, e.g. through the El Niño Southern Oscillation or gradual ocean warming. A good understanding of temperature effects on tunas and billfishes may also be useful in separating the effects of climatic and oceanographic change from the effects of fishing.

While the development of satellite and other tagging technologies has greatly increased our understanding of the distribution patterns of tunas and billfishes (Sedberry \& Loefer 2001, Boustany et al. 2002, Graves et al. 2002, Block et al. 2005), there are still information gaps for particular species. Data regarding water temperature tolerances and preferences were unavailable for any species of spearfish, 2 species of tunas, and sparse for 8 of the species of tuna and billfish studied here. Furthermore, detailed information on the effects of water temperature on spawning behaviour remains poorly resolved. While these data are difficult and time-consuming to obtain, they are essential to aid in our understanding of the factors responsible for tuna and billfish distribution patterns and for informing management and conservation efforts.

Acknowledgements. We gratefully acknowledge access to longline fishing data by the Japanese Fishery agency, NOAA/NMFS and the Australian Fishery Management Agency. The authors thank B. Block and R. A. Myers for inspiration and helpful comments, W. Blanchard, C. Minto, and D. Ricard for statistical advice, and 3 anonymous reviewers for comments and suggestions resulting in improvement to the manuscript. This study was supported by a grant from the National Science and Engineering Research Council of Canada to B.W. and additional funding from The Sloan Foundation (Census of Marine Life FMAP program).

\section{LITERATURE CITED}

Bach P, Dagorn L, Bertrand A, Josse E, Misselis C (2003) Acoustic telemetry versus monitored longline fishing for studying the vertical distribution of pelagic fish: bigeye tuna (Thunnus obesus) in French Polynesia. Fish Res 60: 281-292

Barkley RA, Neill WH, Gooding RM (1978) Skipjack tunas, Katsuwonus pelamis, habitat based on temperature and oxygen requirements. Fish Bull US 76:653-662

Block BA, Stevens DE (2001) Tuna: physiology, ecology, and evolution, Vol 19. Academic Press, Boston, MA

Block BA, Booth DT, Carey FG (1992) Depth and temperature of the blue marlin, Makaira nigricans, observed by acoustic telemetry. Mar Biol 114:175-183

Block BA, Dewar H, Blackwell SB, Williams TD and others (2001) Migratory movements, depth preferences, and thermal biology of Atlantic bluefin tuna. Science 293: 1310-1314

Block BA, Teo SLH, Walli A, Boustany A, Stokesbury M (2005) Electronic tagging and population structure of Atlantic bluefin tuna. Nature 434:1121-1127

Bolton JJ (1994) Global seaweed diversity: patterns and anomalies. Bot Mar 37:241-245

Boustany AM, Davis SF, Pyle P, Anderson SD, LeBoef BJ, Block BA (2002) Satellite tagging: expanded niche for white sharks. Nature 412:35-36

Brill RW (1994) A review of temperature and oxygen tolerance studies of tunas pertinent to fisheries oceanography, movement models and stock assessments. Fish Oceanogr $3: 204-216$

Brill RW, Lutcavage ME (2001) Understanding environmental influences on movements and depth distributions of tunas and billfishes can significantly improve population assessments. Am Fish Soc Symp 25:179-198

Brill R, Holts D, Chang RKC, Sullivan L, Dewar H, Carey FG (1993) Vertical and horizontal movements of striped marlin (Tetrapturus audax) near the Hawaiian Islands, determined by ultrasonic telemetry, with simultaneous measurements of oceanic currents. Mar Biol 117: $567-574$

Brill RW, Lutcavage ME, Metzger G, Bushnell P and others (2002) Horizontal and vertical movements of juvenile bluefin tuna (Thunnus thynnus), in relation to oceanographic conditions of the western North Atlantic, determined with ultrasonic telemetry. Fish Bull 100:155-167

Conkright ME, Locarnini RA, Garcia HE, O'Brien TD, Boyer TP, Stephens C, Antonov JI (2002) World ocean atlas 2001: objective analyses, data statistics, and figures. CD-ROM documentation. National Oceanographic Data Center, Silver Spring, MD

Crame JA (2000) Evolution of taxonomic diversity gradients in the marine realm: evidence from the composition of recent bivalve faunas. Paleobiology 26:198-215

Dickson KA (1995) Unique adaptations of the metabolic biochemistry of tunas and billfishes for life in the pelagic environment. Environ Biol Fish 42:65-97

Fiedler PC, Bernard HJ (1987) Tuna aggregation and feeding near fronts observed in satellite imagery. Cont Shelf Res 7:871-881

Fritsches KA, Brill R, Warrant EJ (2005) Warm eyes provide superior vision in swordfishes. Curr Biol 15:55-58

Fromentin JM, Fonteneau A (2001) Fishing effects and life history traits: a case study comparing tropical versus temperature tunas. Fish Res 53:133-150

Gaston KJ (2000) Global patterns in biodiversity. Nature 405: $220-227$ 
Graves JE, Luckhurst BE, Prince ED (2002) An evaluation of pop-up satellite tags for estimating postrelease survival of blue marlin (Makaira nigricans) from a recreational fishery. Fish Bull 100:134-142

Hanamoto E (1974) Fishery oceanography of bigeye tuna. I. Depth of capture by tuna longline gear in the eastern tropical Pacific Ocean. La Mer 13:58-71

Hanamoto E (1987) Effect of oceanographic environment on bigeye tuna distribution. Bull Jpn Soc Fish Oceanogr 51: 203-216

Hillebrand H (2004) On the generality of the latitudinal diversity gradient. Am Nat 163:192-211

Holts D, Bedford D (1990) Activity patterns of striped marlin in the southern California bight. In: Stroud RH (ed) Planning for the future of billfishes. National Coalition for Marine Conservation, Savannah, GA, p 81-93

ICCAT (2006) Report of the Standing Committee on Research and Statistics (SCRS). International Commission for the Conservation of Atlantic Tunas, Madrid, Spain, October 2 to 6, 2006 (available at. www.iccat.int/Documents/SCRS/ SCRS_2007_ENG.pdf)

Laurs RM, Fiedler PC, Montgomery DR (1984) Albacore catch distributions relative to environmental features observed from satellites. Deep-Sea Res 31:1085-1099

Lee P, Chen I, Tzeng W (2005) Spatial and temporal distribution patterns of bigeye tuna (Thunnus obesus) in the Indian Ocean. Zool Stud 44:260-270

Magnuson JJ, Crowder LB, Medvick PA (1979) Temperature as an ecological resource. Am Zool 19:331-343

Maguire JJ, Sissenwine M, Csirke J, Grainger R, Garcia S (2006) The state of the world's highly migratory, straddling and other high seas fishery resources and associated species. FAO Fish Tech Pap No. 495. FAO, Rome

Myers RA, Worm B (2003) Rapid worldwide depletion of predatory fish communities. Nature 423:280-283

NMFS (2005) Stock assessment and fishery evaluation for Atlantic highly migratory species 2005. National Marine Fisheries Service, Highly Migratory Species Management Division, Silver Spring, MD

Oschlies A, Garçon V (1998) Eddy-induced enhancement of

Editorial responsibility: Howard Browman,

Storebø, Norway primary production in a model of the North Atlantic Ocean. Nature 394:266-269

Pianka ER (1966) Latitudinal gradients in species diversity: a review of concepts. Am Nat 100:33-46

Rex MA, Stuart CT, Hessler RL, Allen JA, Sanders HL, Wilson GDF (1993) Global-scale latitudinal patterns of species diversity in the deep-sea benthos. Nature 365:636-639

Rutherford S, D'Hondt S, Prell W (1999) Environmental controls on the geographic distribution of zooplankton diversity. Nature 400:749-753

Safina C (1998) Song for the blue ocean. Holt, New York

Santos AM (1994) Satellite oceanography applications to the swordfish fishery off Portugal's continental west coast. MSc thesis, University of Lisbon

Sedberry GR, Loefer JK (2001) Satellite telemetry tracking of swordfish, Xiphias gladius, off the eastern United States. Mar Biol 139:355-360

Sharp G (1978) Behavioural and physiological properties of tunas and their effects on vulnerability to fishing gear. In: Sharp GD, Dizon AE (eds) The physiological ecology of tunas. Academic Press, New York, p 397-450

Sibert J, Hampton J, Kleiber P, Maunder M (2006) Biomass, size, and trophic status of top predators in the Pacific Ocean. Science 314:1773-1776

Sund PN, Blackburn M, Williams F (1981) Tunas and their environment in the Pacific Ocean: a review. Oceanogr Mar Biol Annu Rev 19:443-512

Teo SLH, Boustany A, Dewar H, Stokesbury MJW and others (2007) Annual migrations, diving behavior, and thermal biology of Atlantic bluefin tuna (Thunnus thynnus), on their Gulf of Mexico breeding grounds. Mar Biol 151:1-18

Wolanski E, Hamner WM (1988) Topographically controlled fronts in the ocean and their biological influence. Science 241:177-181

Worm B, Lotze HK, Myers RA (2003) Predator diversity hotspots in the blue ocean. Proc Natl Acad Sci USA 100: 9884-9888

Worm B, Sandow M, Oschlies A, Lotze HK, Myers RA (2005) Global patterns of predator diversity in the open oceans. Science 309:1365-1369

Submitted: October 10, 2006; Accepted: September 5, 2007 Proofs received from author(s): February 8, 2008 